\title{
Iridoid glucosides from Pentas lanceolata (Forssk.) Deflers growing on the Island of Sardinia
}

\author{
Alessandro Venditti - Laura Guarcini • \\ Mauro Ballero · Armandodoriano Bianco
}

Received: 10 February 2014/ Accepted: 11 June 2014

(C) Springer-Verlag Wien 2014

\begin{abstract}
The ethanolic extract of Pentas lanceolata (Forssk.) Deflers was investigated from a phytochemical point of view and in particular on the monoterpenoid glucosides content. Iridoid glucosides have a taxonomic relevance, e.g., asperuloside and its derivative are characteristic of the Rubioideae subfamily where this species is comprised. In the light of earliest phylogenetic molecular study which proposed to merge P. lanceolata in the Spermacoceae tribe, a phytochemical approach also becomes necessary for a correct classification of this species. A total of 12 compounds were identified in detail, ten of these are iridoid glucosides: asperuloside, asperulosidic acid, tudoside, $E$-uenfoside and $Z$-uenfoside previously identified in this genus; whereas, deacetyl-asperulosidic acid, ixoside, griselinoside, 6 $6,7 \beta$-epoxysplendoside were recognized here for the first time from $P$. lanceolata. Among the noniridoidic compounds ursolic acid and D-xylose were identified.
\end{abstract}

Keywords Pentas lanceolata $\cdot$ Rubiaceae $\cdot$ Iridoids . Chemotaxonomy

A. Venditti · L. Guarcini · A. Bianco

Department of Chemistry, University of Roma "La Sapienza", Piazzale Aldo Moro, 5, 00185 Rome, Italy

A. Venditti $(\bowtie)$

Department of Environmental Biology, University of Roma

"La Sapienza", Piazzale Aldo Moro, 5, 00185 Rome, Italy

e-mail: alessandro.venditti@uniroma1.it

M. Ballero

Dipartimento di Scienze Botaniche, Consorzio Interuniversitario CoSMeSe, Università di Cagliari, Monserrato, Italy

\section{Introduction}

Pentas lanceolata (Forssk.) Deflers (Egyptian star flower) is a shrub with developed branches which grows up to 90-100 cm. The leaves are dark green, wrinkled, lanceolate that arise rough to the touch, the flowering starts from spring and is characterized by the presence of numerous small star-shaped flowers of red, pink or white color, with umbrella inflorescences. This species belongs to Rubiaceae family, originating from East Africa to Arabia (Verdcourt 1976), it is widely used as decorative plant, principally for building of "Butterfly Garden", because of the prolonged flowering period that reaches the autumn. Flowering plants are attractive to butterfly, bees and other insects. Some ethnobotanical uses of this plant in its place of origin are also known, mainly as anti-malarial (Wanyoike et al. 2004; Kigondu et al. 2001; Endale et al. 2012), against lung diseases (Van Puyvelde et al. 1994) and for wound-healing properties (Nayak et al. 2005). In this study, we report the analysis of the polar fraction obtained from the aerial parts of a sample collected from a spontaneous population growing in the Island of Sardinia.

In particular, we focused our attention on the iridoid glucosides content because this kind of substances is considered chemotaxonomic markers in the Rubiaceae family. Previous study on this species reported the identification of several iridoid glucosides, named tudoside, 13R-epi-gaertneroside, 13R-epi-epoxygaertneroside and a mixture of two isomers $E$ - and $Z$-uenfoside (Schripsema et al. 2007), together with asperuloside and asperulosidic acid which have been found to be characteristic of the Rubioideae subfamily (Bianco et al. 1978; Inouye et al. 1988; Bianco 1990; Vieira et al. 1999; Schripsema et al. 2007; Serrilli et al. 2008; Venditti et al. 2014). Since the systematic of this family is very complex, with division into subfamily 
and tribe, the aim of this study was to deepen the knowledge about the monoterpenoid glucosides pattern of this species and also to give some indications from a chemotaxonomic point of view for a correct classification of $P$. lanceolata. In the past the genus Pentas was placed in the Oldenlandieae, subfamily Cinchonoideae by Schumann (1897), but more recently this genus was moved into the Hedyotideae, subfamily Rubioideae by Verdcourt (1958) where is currently classified. Lately a revision of the subfamily Rubioideae was proposed on the basis of the phylogenetic analysis of molecular data which would include this genus in the tribe Spermacoceae (Bremer and Manen 2000).

\section{Materials and methods}

\section{General}

NMR spectra were recorded on Varian Mercury $300 \mathrm{MHz}$ and/or on Bruker Avance $400 \mathrm{MHz}$ instrument using $\mathrm{CD}_{3} \mathrm{OD}$ or $\mathrm{D}_{2} \mathrm{O}$ as deuterated solvents; the chemical shift was expressed in ppm from TMS.

MS spectra were performed on a Q-TOF MICRO spectrometer (Micromass, now Waters, Manchester, UK) equipped with an ESI source, that operated in the negative and/or positive ion mode. The flow rate of sample infusion was $10 \mu \mathrm{L} / \mathrm{min}$ with 100 acquisitions per spectrum. Data were analyzed by using the MassLynx software developed by Waters.

Solvents of RPE grade were purchased from Sigma Aldrich or Carlo Erba Reagenti, silica gel 60 (70-230 mesh ASTM) from Fluka.

\section{Plant materials}

Plant materials were collected in Sardinia and the botanical identification was performed by one of us (M.B). A sample of the studied plant is stored in our laboratory under the accession number PLF200709CA.

\section{Extraction and isolation of polar compounds}

The dried plant materials $(55.4 \mathrm{~g})$ were exhaustively extracted four times using $96 \%$ ethanol $(0.35 \mathrm{~L}$ each, for $48 \mathrm{~h}$ ). The extracts were collected and the ethanol was eliminated at reduced pressure until a water suspension was obtained. The suspension was frozen and then lyophilized, to preserve temperature-sensitive compounds, obtaining $4.32 \mathrm{~g}$ of crude extract. A preliminary purification by $\mathrm{CC}$ over silica gel $(40.0 \mathrm{~g})$ was performed on $2.01 \mathrm{~g}$ of the crude extract using butanol saturated with water as eluting solvent. From this separation step a low polarity fraction (Fr. 1-3) was recovered where the presence of low polarity compounds was evidenced by ${ }^{1} \mathrm{H}-$ NMR. The (Fr. 6) fraction contained a mixture $(\sim 2: 1)$ $(8.7 \mathrm{mg})$ of $E$-uenfoside (5) and Z-uenfoside (6) (Schripsema et al. 2007) with a minor presence of a third compound (7) which might be also an iridoidic compound on the basis of the resonances visible in the ${ }^{1} \mathrm{H}$-NMR spectra. tudoside (4) (20.1 mg) was eluted as pure compound (Fr. 11-13), followed by fractions where different mixture of iridoids were contained (Fr. 21-25 and Fr. 32-58). The more polar fractions (Fr. 60-82), where sugars were the main compounds, resulted positive to vanillin/ $\mathrm{HCl}$ test evidencing also the presence of iridoidic compounds. These last ones (Fr. 60-82) (286.4 mg) were added with activated charcoal until no reaction to vanillin/ $\mathrm{HCl}$ reagent. The obtained suspension, stratified on a sintered Gooch funnel, was first washed with water to remove the saccharides, then was eluted with methanol $30 \%$ in water recovering a mixture of iridoids very similar to (Fr. 32-58) which was gathered with (Fr. 32-58) for further purification. By desorbing the charcoal with $70 \%$ methanol in water griselinoside (9) $(2.0 \mathrm{mg}$ ) (Ono et al. 2006) was eluted. Fractions (Fr. 95-100) contained a mixture of saccharides of which d-xylose (12) $(30.3 \mathrm{mg}$ ) (Breitmaier and Voelter 1990) was the main component. The low polarity fractions (Fr. 1-3) (590 mg) was purified on silica gel $(18.0 \mathrm{~g})$ using a different eluting mixture. The chromatographic run started with chloroform/methanol (98:2, $\mathrm{v} / \mathrm{v}$ ) and the polarity was gradually increased to $95: 5, \mathrm{v} / \mathrm{v}$ and then to $9: 1, \mathrm{v} / \mathrm{v}$. This separation allowed to recover ursolic acid (11) (25.4 mg) (Gnoatto et al. 2008) as pure compound, among waxes and long chain fatty acids. The remaining fractions, containing mixtures of iridoids, were gathered in one (Fr. 21-58) (347 mg) and re-chromatographed on silica gel $(12.0 \mathrm{~g})$ using chloroform/methanol as mobile phase. The column was conditioned with chloroform/methanol $9: 1, \mathrm{v} / \mathrm{v}$ and the chromatographic run started with $8: 2, \mathrm{v} / \mathrm{v}$ mixture, then the polarity was gradually increased to $7: 3$ and finally to $6: 4$, v/v. The following compounds were eluted: asperuloside (1) (Fr. 15-18) (15.2 mg) (Inouye et al. 1964, 1970), 6 $\beta, 7 \beta$-Epoxysplendoside (10) (Fr. 22-23) (2.2 mg) (Jensen and Nielsen 1982), asperulosidic acid (2) (Fr. 26-30) (4.8 mg) (Bianco et al. 1978, 1981), deacetyl-asperulosidic acid (3) (Fr. 38-42) (6.2 mg) (Inouye et al. 1969; Bianco et al. 1978, 1981), ixoside (8) (Fr. 50-56) (3.1 mg). All the isolated compounds were identified by comparison with literature data and/or direct comparison with standard compounds available in our laboratory.

Asperuloside (1): ${ }^{1} \mathrm{H}-\mathrm{NMR}, \mathrm{CD}_{3} \mathrm{OD}, 300 \mathrm{MHz}, \delta 7.30$ (1H, bs, H-3), $5.96(1 \mathrm{H}, \mathrm{bs}, \mathrm{H}-7), 5.73(1 \mathrm{H}, \mathrm{bs}, \mathrm{H}-1), 5.51$ $(1 \mathrm{H}, \mathrm{d}, J=6.0 \mathrm{~Hz}, \mathrm{H}-6), 4.80$ (partially overlapped with HDO signal, H1' $), 4.66(2 \mathrm{H}, \mathrm{d}, J=12.3 \mathrm{~Hz}, \mathrm{H}-10), \mathrm{H}-5$ 
<smiles>CC(=O)OCC1=C[C@@H]2OC(=O)C3=CO[C@H](OC(C)=O)C4C(COC(C)=O)C2C1C34</smiles>

Asperuloside (1)<smiles>O=C(O)C1=CO[C@@H](O)C2C(CO)=C[C@H](O)[C@H]12</smiles>

deacetyl-asperulosidic acid (3)<smiles>COC(=O)C1=CO[C@@H](O)C2C1C1OC1[C@@]2(O)C=O</smiles>

(4) tudoside

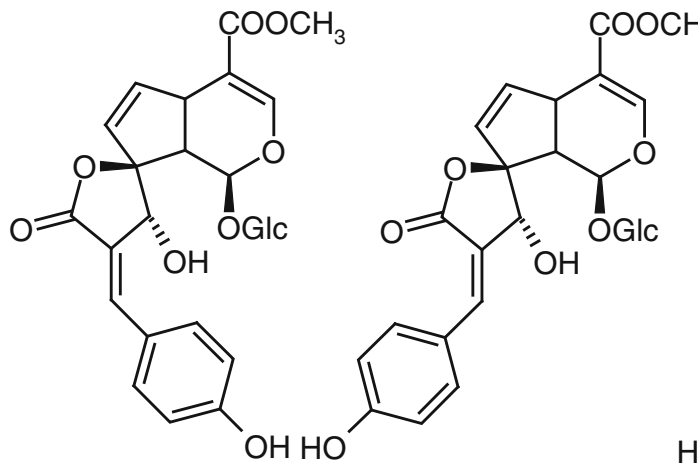

(5) E-uenfoside

(6) Z-uenfoside<smiles>CC(=O)C1=CO[C@H](O)C2C1C1=C(O1)[C@@]21OC(=O)/C(=C\c2ccc(O)cc2)[C@@H]1O</smiles>

compound (7)

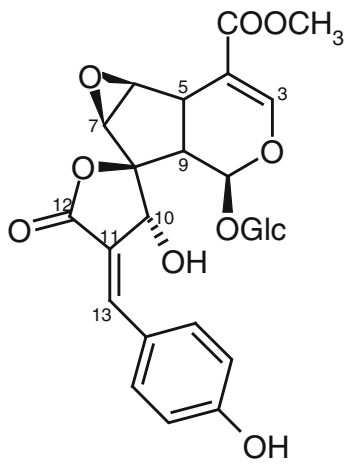

citrifolinoside $A$<smiles>CO[C@@H]1OC=C(C(=O)O)C2CC=C(C(=O)O)C21</smiles>

(8) ixoside<smiles>COC(=O)C1=CO[C@@H](OC)C2C(C(=O)OC)CC(=O)C12</smiles>

(9) griselinoside<smiles>CC(=O)OC1OC(C(C)=O)C2C1C1OC1[C@@]2(O)CO</smiles>

(10) $6 \beta, 7 \beta$-epoxysplendoside

Fig. 1 Iridoid glucosides from P. lanceolata

and $\mathrm{H}-9$ overlapped with sugar signals, $2.14\left(3 \mathrm{H}, s, \underline{\mathrm{CH}_{3}}-\right.$ CO). HR-ESI-MS: $m / z, 437.09[\mathrm{M}+\mathrm{Na}]^{+}$.

Asperulosidic acid (2): ${ }^{1} \mathrm{H}-\mathrm{NMR}, \mathrm{D}_{2} \mathrm{O}, 400 \mathrm{MHz}, \delta 7.44$ $(1 \mathrm{H}, \mathrm{d}, J=2.2 \mathrm{~Hz}, \mathrm{H}-3), 6.07(1 \mathrm{H}, \mathrm{d}, J=2.0 \mathrm{~Hz}, \mathrm{H}-1)$, $5.84\left(1 \mathrm{H}\right.$, bs, H-7), $4.89\left(1 \mathrm{H}, \mathrm{d}, J=8.0 \mathrm{~Hz}, \mathrm{H}^{\prime}\right), 4.74$ (partially overlapped with HDO signal a $4.78 \mathrm{ppm}, \mathrm{H}-6$ ), 3.09 (1H, $t, J=3 \mathrm{~Hz}, \mathrm{H}-9), 2.75$ (1H, $t, J=8.2 \mathrm{~Hz}, \mathrm{H}-5)$, $2.15\left(3 \mathrm{H}, \mathrm{s}, \mathrm{CH}_{3} \mathrm{CO}\right)$. ESI-MS: $\mathrm{m} / \mathrm{z} 431.26[\mathrm{M}-\mathrm{H}]^{-} ; \mathrm{m} / \mathrm{z}$ $455.05[\mathrm{M}+\overline{\mathrm{Na}}]^{+}$.

Deacetyl-asperulosidic acid (3): ${ }^{1} \mathrm{H}-\mathrm{NMR}, \mathrm{CD}_{3} \mathrm{OD}$, $300 \mathrm{MHz}, \delta 7.56(1 \mathrm{H}, \mathrm{s}, \mathrm{H}-3), 5.90(1 \mathrm{H}, \mathrm{bs}, \mathrm{H}-7), 5.31$ $(1 \mathrm{H}, \mathrm{bs}, \mathrm{H}-1), 5.10(1 \mathrm{H}, \mathrm{d}, J=8.7 \mathrm{~Hz}, \mathrm{H}-6), 4.76(1 \mathrm{H}, \mathrm{d}$, $\left.J=7.7 \mathrm{~Hz}, \mathrm{H}-1^{\prime}\right), 4.22(2 \mathrm{H}, \mathrm{bd}, J=13 \mathrm{~Hz}, \mathrm{H}-10), 3.02$ $(1 \mathrm{H}, \mathrm{bt}, J=6.5 \mathrm{~Hz}, \mathrm{H}-9), 2.55(1 \mathrm{H}$, bt $J=7.7 \mathrm{~Hz}, \mathrm{H}-5)$. ESI-MS: $m / z, 413.28[\mathrm{M}+\mathrm{Na}]^{+}$.

Tudoside (4) : ${ }^{1} \mathrm{H}-\mathrm{NMR}\left(300 \mathrm{MHz}, \mathrm{CD}_{3} \mathrm{OD}\right) \delta 9.54$ $(1 \mathrm{H}, s, \mathrm{H}-10), 7.35(1 \mathrm{H}, \mathrm{s}, \mathrm{H}-3), 5.76(1 \mathrm{H}, \mathrm{s}, \mathrm{H}-1), 3.74$ $\left(3 \mathrm{H}, \mathrm{s},-\mathrm{OC} \underline{H_{3}}\right), 3.39$ (overlapped, H-5), $2.44(1 \mathrm{H}, \mathrm{d}$, $J=8.4 \mathrm{~Hz}, \mathrm{H}-9) .{ }^{13} \mathrm{C}-\mathrm{NMR}\left(75 \mathrm{MHz}, \mathrm{CD}_{3} \mathrm{OD}\right) \delta 201.99$
(C-10, aldehyde), 168.54 (C-11), 154.66 (C-3), 107.28 (C-4), 99.84 (C-10 Hydrated aldehyde), 98.31 (C-1'), 93.92 (C-1), 82.06 (C-8), $78.22\left(\mathrm{C}-3^{\prime}\right), 77.87\left(\mathrm{C}-5^{\prime}\right), 74.44\left(\mathrm{C}-2^{\prime}\right)$, $71.47\left(\mathrm{C}-4^{\prime}\right), 62.83\left(\mathrm{C}-6^{\prime}\right), 51.68\left(-\mathrm{OCH}_{3}\right), 46.80(\mathrm{C}-9)$, 33.30 (C-5). ESI-MS: $m / z, 473.17[\mathrm{M}+\overline{\mathrm{Na}}]^{+}$.

E-Uenfoside (5): ${ }^{1} \mathrm{H}-\mathrm{NMR}\left(400 \mathrm{MHz}, \mathrm{CD}_{3} \mathrm{OD}\right) \delta 7.69$ $\left(2 \mathrm{H}, \mathrm{d}, J=8.7 \mathrm{~Hz}, \mathrm{H}-2^{\prime}, \mathrm{H}-6^{\prime}\right), 7.61(1 \mathrm{H}, s, \mathrm{H}-13), 7.47$ $(1 \mathrm{H}, \mathrm{d}, J=1.6 \mathrm{~Hz}, \mathrm{H}-3), 6.89\left(2 \mathrm{H}, \mathrm{d}, J=8.6 \mathrm{~Hz}, \mathrm{H}-3^{\prime}\right.$, H-5'), $6.46(1 \mathrm{H}, \mathrm{dd}, J=5.8,2.3 \mathrm{~Hz}, 7-\mathrm{H}), 6.10(1 \mathrm{H}, \mathrm{dd}$, $J=5.8,2.5 \mathrm{~Hz}, \mathrm{H}-6), 5.21(1 \mathrm{H}, \mathrm{d}, J=6.1 \mathrm{~Hz}, \mathrm{H}-1), 4.61$ $\left(1 \mathrm{H}, \mathrm{d}, J=8.0 \mathrm{~Hz}, \mathrm{H}-1^{\prime \prime}\right), 3.92-3.86(1 \mathrm{H}, m, \mathrm{H}-5), 3.75$ (3H, $\left.s, \mathrm{OCH}_{3}\right), 2.55(1 \mathrm{H}, \mathrm{dd}, J=6.9,6.5 \mathrm{~Hz}, \mathrm{H}-9)$. ESIMS: $m / z 546.78[\mathrm{M}-\mathrm{H}]^{-} ; \mathrm{m} / z 570.78[\mathrm{M}+\mathrm{Na}]^{+}$.

Z-Uenfoside (6) : ${ }^{1} \mathrm{H}-\mathrm{NMR}\left(400 \mathrm{MHz}, \mathrm{CD}_{3} \mathrm{OD}\right) \delta 7.98$ $\left(2 \mathrm{H}, \mathrm{d}, J=8.7 \mathrm{~Hz}, \mathrm{H}-2^{\prime}, \mathrm{H}-6^{\prime}\right), 7.50(1 \mathrm{H}, \mathrm{d}, J=1.7 \mathrm{~Hz}$, H-3), $7.08(1 \mathrm{H}, \mathrm{d}, J=2.2 \mathrm{~Hz}, \mathrm{H}-13), 6.80(2 \mathrm{H}, \mathrm{d}$, $\left.J=8.8 \mathrm{~Hz}, \mathrm{H}-3^{\prime} ; \mathrm{H}^{-} 5^{\prime}\right), 6.39(1 \mathrm{H}, \mathrm{dd}, J=5.8,2.4 \mathrm{~Hz}$, H-7), $5.88(1 \mathrm{H}, \mathrm{dd}, J=5.7,2.4 \mathrm{~Hz}, \mathrm{H}-6), 5.45(1 \mathrm{H}, \mathrm{d}$, $J=5.5 \mathrm{~Hz}, \mathrm{H}-1), 5.31(1 \mathrm{H}, \mathrm{d}, J=1.8 \mathrm{~Hz}, \mathrm{H}-10), 4.75$ 
$\left(1 \mathrm{H}, \mathrm{d}, J=7.8 \mathrm{~Hz}, \mathrm{H}-1^{\prime \prime}\right), 3.87(1 \mathrm{H}, m, \mathrm{H}-5), 3.75$ (3H, $s$, $\left.-\mathrm{OCH}_{3}\right), 2.78(1 \mathrm{H}, \mathrm{dd}, J=7.3,5.6 \mathrm{~Hz}, \mathrm{H}-9)$. ESI-MS: $m / z$ $546 . \overline{78}[\mathrm{M}-\mathrm{H}]^{-} ; \mathrm{m} / z 570.78[\mathrm{M}+\mathrm{Na}]^{+}$.

Compound (7) : ${ }^{1} \mathrm{H}-\mathrm{NMR}\left(400 \mathrm{MHz} \mathrm{CD}_{3} \mathrm{OD}\right) \delta 8.06$ ( $\left.2 \mathrm{H}, \mathrm{d}, J=8.6 \mathrm{~Hz}, \mathrm{H} 2^{\prime \prime}, \mathrm{H6}^{\prime \prime}\right), 7.59$ (1H, s, H13), 7.46 $(1 \mathrm{H}, \mathrm{d}, J=3.2 \mathrm{~Hz}, \mathrm{H} 3), 6.82(2 \mathrm{H}, \mathrm{d}, J=8.6 \mathrm{~Hz}$, $\left.\mathrm{H}^{\prime \prime}, \mathrm{H}^{\prime \prime}\right), 5.14(1 \mathrm{H}, \mathrm{s}, \mathrm{H} 10), 2.78(1 \mathrm{H}, \mathrm{dd}, J=7.0$, $5.9 \mathrm{~Hz}, \mathrm{H} 9)$. ESI-MS: $\mathrm{m} / \mathrm{z} 562.75[\mathrm{M}-\mathrm{H}]^{-} ; \mathrm{m} / \mathrm{z} 586.73$ $[\mathrm{M}+\mathrm{Na}]^{+}$.

Ixoside (8): ${ }^{1} \mathrm{H}-\mathrm{NMR}\left(300 \mathrm{MHz}, \mathrm{D}_{2} \mathrm{O}\right) \delta 7.53(1 \mathrm{H}, \mathrm{bs}$, H-3), 7.03 (1H, m, H-7), 5.76 (1H, d, $J=4.6 \mathrm{~Hz}, \mathrm{H}-1)$, 3.20 (1H, overlapped with sugar signals, H-9), 3.04 (1H, bt, $J=5.6 \mathrm{~Hz}, \mathrm{H}-5), 2.69-2.46$ (2H, m, H-6). ESI-MS: $m / z$ $411.20[\mathrm{M}+\mathrm{Na}]^{+}$.

Griselinoside (9): ${ }^{1} \mathrm{H}-\mathrm{NMR}\left(300 \mathrm{MHz}, \mathrm{D}_{2} \mathrm{O}\right) \quad \delta 7.64$ (1H, bs, H-3), $5.34(1 \mathrm{H}, \mathrm{d}, J=6 \mathrm{~Hz}, \mathrm{H} 1), 3.81(3 \mathrm{H}, \mathrm{s}$, $\left.-\mathrm{OC}_{\underline{H_{3}}}\right), 3.74\left(3 \mathrm{H}, \mathrm{s},-\mathrm{OC} \underline{H_{3}}\right.$ ), 3.51 (overlapped with sugar signal, H-5), 2.76 (partially overlapped with sugar signal, H-9), 2.20-1.97 (2H, m, H-7). ${ }^{13} \mathrm{C}-\mathrm{NMR}$ (75 MHz, D $\left.2 \mathrm{O}\right) \delta$ 211.8 (C-6), 175.8 (C-10), 169.0 (C-11), 153.8 (C-3), 104.5 (C-4), $99.1\left(\mathrm{C}-1^{\prime}\right), 96.6(\mathrm{C}-1), 76.3\left(\mathrm{C}-3^{\prime}\right), 75.5\left(\mathrm{C}-5^{\prime}\right), 72.6$ $\left(\mathrm{C}-2^{\prime}\right), 69.3\left(\mathrm{C}-4^{\prime}\right), 62.5\left(\mathrm{C}-6^{\prime}\right), 52.1\left(-\mathrm{OC}^{-} \mathrm{H}_{3}\right), 45.12(\mathrm{C}-9)$, 39.5 (C-8), 38.1 (C-7). ESI-MS: $m / z 431.09$ [M-H] ${ }^{-} ; m / z$ $455.16[\mathrm{M}+\mathrm{Na}]^{+}$.

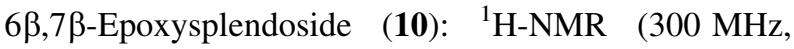
$\left.\mathrm{D}_{2} \mathrm{O}\right) \delta 7.52$ (1H, bs, H-3), $5.65(1 \mathrm{H}, \mathrm{bd}, J=6.9 \mathrm{~Hz}, \mathrm{H}-1)$, $4.89\left(1 \mathrm{H}, \mathrm{d}, J=7.8 \mathrm{~Hz}, \mathrm{H}-1^{\prime}\right), 4.01(1 \mathrm{H}, \mathrm{bd}, J=3.0 \mathrm{~Hz}$, $\mathrm{H}-6), 3.75\left(3 \mathrm{H}, \mathrm{s},-\mathrm{OC} \mathrm{H}_{3}\right), 3.18(1 \mathrm{H}$, partially overlapped with sugar signals, H-5), $2.58(1 \mathrm{H}, b t, J=7.2 \mathrm{~Hz}, \mathrm{H}-9)$. ESI-MS: $m / z, 433.19[\mathrm{M}+\mathrm{Na}]^{+}$.

Ursolic acid (11) : ${ }^{1} \mathrm{H}-\mathrm{NMR}$ (400 $\left.\mathrm{MHz} \mathrm{CD}_{3} \mathrm{OD}\right) \delta 5.23$ $(1 \mathrm{H}, \mathrm{t}, J=3.6 \mathrm{~Hz}, \mathrm{H}-12), 3.15(1 \mathrm{H}, \mathrm{dd}, J=11.2,5.0 \mathrm{~Hz}$, $\mathrm{H}-3), 2.20$ (1H, d, J=11.0 Hz, H-18), 2.04 (1H, td, $J=13.4,4.1 \mathrm{~Hz}, \mathrm{H}-15 \mathrm{a}), 1.93(1 \mathrm{H}, \mathrm{dd}, J=8.7,3.7 \mathrm{~Hz}$, H-16a), 1.12 (3H, s, H-27), 0.98 (3H, s, H-23), 0.97 (3H, d, $J=6.8 \mathrm{~Hz}, \mathrm{H}-29), 0.96(3 \mathrm{H}, \mathrm{s}, \mathrm{H}-26), 0.88(3 \mathrm{H}, \mathrm{d}$, $J=6.5 \mathrm{~Hz}, \mathrm{H}-30), 0.85$ (3H, s, H-24), 0.78 (3H, s, H-25). ${ }^{13} \mathrm{C}-\mathrm{NMR}$ (101 MHz, MeOD) $\delta 181.74$ (C-28), 139.68 (C-13), 126.95 (C-12), 79.76 (C-3), 56.79 (C-5), 54.42 (C-18), 49.21 (C-17), 48.63 (C-9), 43.29 (C-14), 40.83 (C-4), 40.47 (C-19), 40.46 (C-20), 40.05 (C-1), 39.88 (C-8), 38.15 (C-10; C-22), 34.38 (C-7), 31.81(C-21), 29.26 (C-23), 28.82 (C-2), 27.94 (C-15), 25.37 (C-16), 24.41 (C-27), 24.14 (C-11), 21.62 (C-30), 19.52 (C-6), 17.86 (C-29), 17.69 (C-24), 16.43 (C-26), 16.07 (C-25). ESI-MS: $m / z 455.05[\mathrm{M}-\mathrm{H}]^{-} ; m / z 479.04[\mathrm{M}+\mathrm{Na}]^{+}$.

d-Xylose (12): ${ }^{1} \mathrm{H}-\mathrm{NMR}\left(300 \mathrm{MHz}, \mathrm{D}_{2} \mathrm{O}\right) \delta 5.2(1 \mathrm{H}, \mathrm{d}$, $J=3 \mathrm{~Hz}, \mathrm{H} 1 \alpha), 4.62$ (1H, d, $J=8.8 \mathrm{~Hz}, \mathrm{H} 1 \beta), 4.14-3.18$ overlapped $\mathrm{CH}$ signals. ${ }^{13} \mathrm{C}-\mathrm{NMR}\left(75 \mathrm{MHz}, \mathrm{D}_{2} \mathrm{O}\right) \delta 96.02$

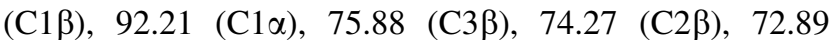

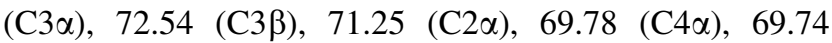

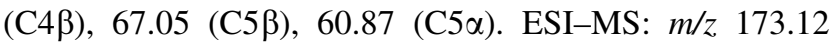
$[\mathrm{M}+\mathrm{Na}]^{+}$.

\section{Results and discussion}

The analysis of the ethanolic extract obtained from the aerial parts of $P$. lanceolata led mainly to isolation of iridoid glucosides (Fig. 1). Ursolic acid and a monosaccharide, d-xylose (Fig. 2) were also identified in minor amount. Compounds (1) asperuloside and (2) asperulosidic acid were already identified in P. lanceolata (Inouye et al. 1988) while compound (3), deacetyl-asperulosidic acid, was recognized for the first time in this study. These derivatives $(\mathbf{1}, \mathbf{2}, \mathbf{3})$ are considered chemotaxonomic markers for the subfamily Rubioideae. Tudoside (4) resulted the main iridoidic component as well as in the previous analyses of this species (Schripsema et al. 2007). We also evidenced a notable amount of a mixture $(\sim 2: 1)$ composed of $E$-uenfoside (5) and $Z$-uenfoside (6) and a minor quantity of a third component (7). This compound (7), could be an iridoidic substance featured with a spironolactone functionality and provided with a para-hydroxybenzene moiety (evidenced by two sets of doublets in the aromatic region at $6.82 \mathrm{ppm}$ and relative to $\mathrm{H} 3^{\prime \prime}$ and $\mathrm{H}^{\prime \prime}$ and the more deshielded at $8.06 \mathrm{ppm}$ relative to $\mathrm{H} 2^{\prime \prime}$ and $\mathrm{H}^{\prime \prime}$, both coupling constants of $8.6 \mathrm{~Hz}$ ). A singlet at $\delta 7.59$ which could be assigned to H13, a doublet at $\delta 7.46(1.9 \mathrm{~Hz})$ for $\mathrm{H} 3$, a singlet at $\delta 5.14$ for $\mathrm{H} 10$ and a double doublets $\delta 2.78$ $(7.0 / 5.9 \mathrm{~Hz})$ for $\mathrm{H} 9$ were also evident. Probably there is no double bond between $\mathrm{C} 6$ and $\mathrm{C} 7$, but reasonably an epoxide function, which causes a shift effect on the H6 and H7 signals to about 4.0-3.8 ppm might be hypothesized in these positions. All these signals, compared with the respective signals of citrifolinoside A (Sang et al. 2001), seemed to be shifted in the same manner as in the couple of epimers $E$ - and $Z$-uenfoside. In particular, the doublet relative to $\mathrm{H}^{\prime \prime}$ and $\mathrm{H}^{\prime \prime}$ resulted more deshielded in the $\mathrm{Z}$-isomer, whereas the doublet of $\mathrm{H}^{\prime \prime}$ and $\mathrm{H}^{\prime \prime}$ resulted shifted at higher field in the $Z$-isomer; H9 has also a similar deshielding effect in the $Z$-isomer. All these data seemed to be in accordance with the presence of the $Z$-epimer of citrifolinoside A, of which we could hypothesize the presence, also on the basis of corresponding mass

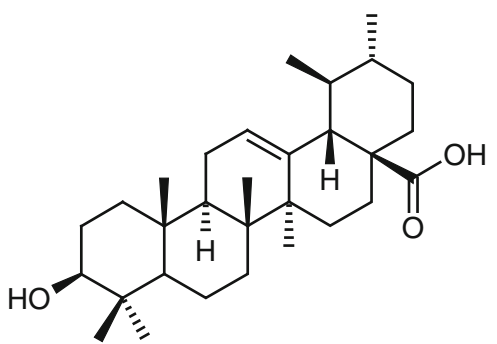

Ursolic acid (11)<smiles>O[C@H]1CO[C@H](O)[C@@H](O)[C@H]1O</smiles>

D-xylose (12)
Fig. 2 Non-iridoidic compounds isolated from P. lanceolata 
spectrometric signals both in negative and positive ionization mode $\left(\mathrm{m} / \mathrm{z} 562.75[\mathrm{M}-\mathrm{H}]^{-} ; \mathrm{m} / z 586.73[\mathrm{M}+\mathrm{Na}]^{+}\right)$. Surely, further study on this aspect should be conducted to confirm or not this hypothesis. From both, chemical and chemotaxonomic point of view, compounds (5) and (6) [and also compound (7) if confirmed] are very particular substances due to their spironolactone functionality which is a very rare feature among iridoids isolated from the Rubiaceae family. Similar compounds have been previously recognized in Morinda citrifolia (citrifolinoside A), (Sang et al. 2001) and in M. coreia (yopaaoside A and B, structures not reported) (Kanchanapoom et al. 2002). Recently the structures of yopaaoside A and B were revised in particular for the configuration at C-8 and C-10. NMR data for yopaaoside A were found to be identical to those reported for citrifolinoside, whereas yopaaoside B was revised to citrifolinoside A (Schripsema et al. 2006).

Morinda citrifolia and M. coreia are comprised in the Psychotria tribe of Rubioideae, a tribe very near to Spermacoceae where $P$. lanceolata should be placed on the basis of the earliest phylogenetic analysis of molecular data (Bremer and Manen 2000).

Ixoside (8) firstly isolated by Takeda (1975) is an iridoid characteristic of the genus Ixora which is comprised in the subfamily Ixoroideae of Rubiaceae, but was also isolated from Tarenna kotoensis (Takeda et al. 1976) which belongs to a different subfamily (Cinchonoideae). Considering the occurrence of this compound this is the first report on isolation of ixoside (8) from a genus belonging to $\mathrm{Ru}$ bioideae subfamily. Ixoside (8) was also recognized in species belonging to different families as Dolichandrone serriculata (Bignoniaceae) (Sinaphet et al. 2006) and Leonotis nepetaefolia (Takeda et al. 1999) (Lamiaceae), both families, as Rubiaceae, are comprised in the Subclass Asteridae.

Particularly interesting was the identification of compound (9) griselinoside, because this substance was mainly isolated from Verbena spp. (Verbenaceae) (Damtoft et al. 1979; Pagani 1984; Ono et al. 2006) and from Toricellia angulata (Cornaceae) (Wu et al. 2000), and is reported here for the first time from a Rubiaceae species.

$6 \beta, 7 \beta$-Epoxysplendoside (10) was primarily recognized in Fouqiueira spp. (Ericales) (Jensen and Nielsen 1982) and lately was isolated also from M. citrifolia (Sang et al. 2002). This compound has an epoxy group at C6-C7 in the same configuration of tudoside (4), the major compound recognized in $P$. lanceolata.

The last two isolated compounds, ursolic acid (11) and d-xylose (12), have no particular importance from a chemosystematic point of view since pentacyclic triterpenes are widely distributed in the plant kingdom as the monosaccharides, but were recognized here for the first time in P. lanceolata.
In conclusion, regarding the presence of iridoid glycosides, we documented a composition quite similar to those reported in previous studies, but the presence of minor compounds never identified in this species was evidenced. The presence of the same compounds among different species, as compounds (8), (9) and (10), is an evidence of common biochemical pathways and may also reveal their taxonomical proximity. On the other hand, these differences could also have arisen from the different pedological and climatic conditions in which the studied samples have grown. In fact the Sardinian climate and soil are very different with respect to the native places of this species where a tropical climate is present. In support of this last hypothesis, the influence of the Sardinian environment on the phenotype expression, we have previously recognized some particular iridoidic pattern in Rubiaceae species (Galium) from Sardinia (Serrilli et al. 2008).

\section{References}

Bianco A, Guiso M, Iavarone C, Passacantilli P, Trogolo C (1978) New iridoid glucosides from rubiaceae. Gazz Chim Ital 108(1-2):13-16

Bianco A, Caciola P, Guiso M, Iavarone C, Trogolo C (1981) Carbon13-nuclear magnetic resonance spectroscopy of free iridoid glucosides in $\mathrm{D}_{2} \mathrm{O}$ solution. Gazz Chim Ital 111:201

Bianco A (1990) The Chemistry of Iridoids, in, Atta-ur-Rahman Ed., Studies in Natural Products Chemistry, Elsevier, Amsterdam, Vol 7 p. $439-497$

Breitmaier E, Voelter W (1990) Carbon-13-nmr spectroscopy. VCH, New York

Bremer B, Manen JF (2000) Phylogeny and classification of the subfamily rubioideae (rubiaceae). Plant Syst Evol 225(1-4): 43-72

Damtoft S, Jensen SR, Nielsen BJ (1979) Iridoids in Verbena. Taxon 28(5-6):525-528. doi:10.2307/1219790

Endale M, Alao JP, Akala HM, Rono NK, Eyase FL, Derese S, Ndakala A, Mbugua M, Walsh DS, Sunnerhagen P, Erdelyi M, Yenesew A (2012) Antiplasmodial quinones from Pentas longiflora and Pentas lanceolata. Planta Med 78(1):31-35

Gnoatto SCB, Dassonville-Klimpt A, Da Nascimiento S, Galéra P, Boumediene K, Gosmann G, Sonnet P, Moslemi S (2008) Evaluation of ursolic acid isolated from Ilex paraguriensis and derivatives on aromatase inhibition. Eur $\mathrm{J}$ Med Chem 43:1865-1877

Inouye H, Fuji K (1964) Monoterpene glycosides. III. Stereochemical relations between monotropeine, asperuloside, and aucubine, and the absolute configuration of the last. Chem Pharm Bull 12(8):901-905

Inouye H, Okigawa M, Shimokawa N (1969) Monoterpene glucosides. VIII. Artifacts formed during extraction of asperuloside and paederoside. Chem Pharm Bull 17(9):1949-1954

Inouye H, Yoshida T, Tobita S, Okigawa M (1970) Monoterpene glucosides. IX. Chemical correlation between asperuloside loganin. Tetrahedron 26(16):3905-3915

Inouye $\mathrm{H}$, Takeda Y, Nishimura $\mathrm{H}$, Kanomi A, Okuda T, Puff C (1988) Studies on monoterpene glucosides and related natural products. part 61. chemotaxonomic studies of rubiaceous plants containing iridoid glycosides. Phytochemistry 27(8):2591-2598 
Jensen SR, Nielsen BJ (1982) Iridoid glucosides in fouquieriaceae. Phytochemistry 21(7):1623-1629

Kanchanapoom T, Kasai R, Yamasaki K (2002) Iridoid and phenolic glycosides from Morinda coreia. Phytochemistry 59:551-556

Kigondu EVM, Rukunga GM, Gathirwa JW, Irungu BN, Mwikwabe NM, Amalemba GM, Omar SA, Kirira PG (2001) Antiplasmodial and cytotoxicity activities of some selected plants used by the maasai community Kenya. South African J Bot 77(3):725-729

Nayak BS, Vinutha B, Geetha B, Sudha B (2005) Experimental evaluation of Pentas lanceolata flowers for wound healing activity in rats. Fitoterapia 76(7-8):671-675

Ono M, Oishi K, Abe H, Masuoka C, Okawa M, Ikeda T, Nohara T (2006) New Iridoid Glucosides from the Aerial Parts of Verbena brasiliensis. Chem Pharm Bull 54(10):1421-1424

Pagani F (1984) Constituents of Verbena bonariensis L. (Verbenaceae). Boll Chim Farm 123(10):477-482

Sang S, Cheng X, Zhu N, Wang M, Jhoo J-W, Stark RE, Badmaev V, Ghai G, Rosen R-T, Ho C-T (2001) Iridoid Glycosides from the leaves of Morinda citrifolia. J Nat Prod 64:799-800

Sang S, Wang M, He K, Liu G, Dong Z, Badmaev V, Zheng Q-Y, Ghai G, Rosen RT, Ho C-T (2002) Chemical components in noni fruits and leaves (Morinda citrifolia L.). ACS Symp Series 803:134-150

Schripsema J, Caprini GP, Dagnino D (2006) Revisiono f the structure of citrifolinin A, citrifolinoside, Yopaaoside A, Yopaaoside B, and Morindacin, iridoids from Morinda citrifolia L. and Morinda coreia Ham. Org Lett 8(23):5337-5340

Schripsema J, Caprini GP, van der Heijden R, Bino R, de Vos R, Dagnino D (2007) Iridoids from Pentas lanceolata. J Nat Prod 70(9):1495-1498

Schumann K (1897). In: Engler A, Prantil K (eds) Die Naturlichen Pflantzenfamilien, vol 4. Engelmann, Leipzig, Germany, pp 1-56
Serrilli AM, Ramunno A, Amicucci F, Chicarella V, Santoni S, Ballero M, Serafini M, Bianco A (2008) Iridoidic pattern in endemic sardinian plants: the case of Galium species. Nat Prod Res 22(7):618-622

Sinaphet B, Noiarsa P, Rujirawat S, Otsuka H, Kanchanapoom T (2006) Dolichandroside, a new phenolic triglycoside from Dolichandrone serrulata (DC.) Seem. J Nat Med 60(3):251-254

Takeda Y, Nishimura H, Inouye H (1976) Studies on monoterpene glucosides and related natural products. XXXII. Iridoid glucosides of Tarenna kotoensis var. gyokushinka. Chem Pharm Bull 24(6):1216-1218

Takeda T, Narukawa Y, Hada N (1999) Studies on the constituents of Leonotis nepetaefolia. Chem Pharm Bull 47(2):284-286

Van Puyvelde L, Ntawukiliyayo JD, Portaels F, Hakizamungu E (1994) In vitro inhibition of mycobacteria by Rwandese medicinal plants. Phytother Res 8(2):65-69

Venditti A, Altieri A, Bianco A (2014) Monoterpenoids glycosides content from two mediterranean populations of Crucianella maritima L. Nat Prod Res 28(8):586-588. doi:10.1080/ 14786419.2014.882920

Verdcourt B (1958) Bull Jard Bot État 28:209-290

Verdcourt B (1976) 1976. In: Polhill RM (ed) Flora of Tropical East Africa. Crown agents for overseas governments and administrations; Whitefriars Press, London, pp 1-213

Vieira IJC, Mathias L, Braz-Filho R, Schripsema J (1999) Iridoids from Borreria verticillata. Org Lett 1(8):1169-1171

Wanyoike GN, Chhabra SC, Lang'at-Thoruwa CC, Omar SA (2004) Brine shrimp toxicity and antiplasmodial activity of five Kenyan medicinal plants. J Ethnopharmacol 90(1):129-133

Wu S, Ma Y, Luo X, Wu D, Liu J (2000) Chemical constituent from Toricellia angulata. Yunnan Zhiwu Yanjiu 22(2):214-218 